International Review of Research in Open and Distributed Learning Volume 19, Number 3

July -2018

\title{
Exploring Information Seeking Behavior of Farmers' in Information Related to Climate Change Adaptation Through ICT (CHAI)
}

Siza D. Tumbo ${ }^{1}$, Nicholaus Mwalukasa ${ }^{2}$, Kadeghe G. Fue ${ }^{2}$, Malongo R.S. Mlozi ${ }^{2}$, Ruth Haug², and Camilius A. Sanga ${ }^{2}$ ${ }^{1}$ Centre for Agric. Mechanization and Rural Technologies, Arusha, Tanzania, ${ }^{2}$ Sokoine University of Agriculture, Morogoro, Tanzania

\begin{abstract}
In Tanzania, agriculture sector is known for employing more than $70 \%$ of the total population. Agriculture sector faces many challenges including climate change. Climate change causes low productivity in agriculture; low productivity is caused due to poor implementation of agricultural policies and strategies. This poor implementation of policies has also caused many farmers to be not competent in climate change adaptation. Over the years, provisions of agricultural advice and extension were provided by various approaches, including training and visit extension, participatory approaches, and farmers' field schools. However, provision of agricultural advisory and extension service is inefficient. Also, in most cases the usage of most agricultural innovations and technologies developed is limited. A literature review indicates that the main reasons given by Tanzanian farmers for not using improved technology are not lack of knowledge or skill, but rather that the technologies do not contribute towards improvements (e.g., the technologies are not profitable or they imply to high risk). Thus, agricultural extension service needs to be geared towards teaching farmers how to develop innovative and cost effective technologies that are contextualized. Limited numbers of agricultural extension staff and less interactivity of Information and Communication Technologies (ICTs), such as radio and television, have been mentioned to be among the factors limiting the provision of agricultural advisory and extension services to the majority of farmers in Tanzania. The advancements in ICTs have brought new opportunities for enhancing access to agricultural advisory and extension service for climate change adaptation. In Tanzania, farmers and other actors access agricultural information from various sources such as agricultural extension workers and use of various databases from Internet Services Providers. Also there are different web - and mobile - based farmers' advisory information systems to support conventional agricultural extension service. These systems are producing bulk amounts of data which makes it difficult for different stakeholders to make an informed decision after data analysis. This calls for the need to develop a tool for data visualization in order to understand hidden patterns from massive data. In this study, a semi-automated text classification was developed to determine the frequently asked keywords from a web and mobile based farmers' advisory system called UshauriKilimo after being in use for more than 2 years by more than 700 farmers.
\end{abstract}

Keywords: agro-advisory service, climate change adaptation, information, needs, seeking, behaviour 


\section{Background Information}

Agriculture is the backbone of most African countries (Eicher, 2003; Havnevik Bryceson, Birgegård, Matondi, \& Beyene, 2007; Salami, Kamara, \& Brixiova, 2009; Lwoga, Ngulube, \& Stilwell, 2011). In Tanzania, the sector is known for employing more than $70 \%$ of the total population, contributing about $25 \%$ to the Gross Domestic Product (GDP), bringing about 66\% of the foreign exchange, and providing raw materials for local industries (United Republic of Tanzania [URT], 2008, Haug \& Hella, 2013). The sector also feeds the nation and is the source of livelihoods to most rural communities in the country. However, agriculture is identified as one of the sector's most vulnerable to climate change (Mwandosya, Nyenzi, \& Lubanga, 1998). This has led to difficulty in maintaining food security in most of the countries including Tanzania (Isinika, Hella, \& Moshi, 2016; Haug, 2016). Food security is not only affected by climate change but also other factors including: lack of agricultural support services, weak researchextension-farmer linkages, among others (URT, 2008; Isinika et al., 2016). These factors hinder agricultural policies and strategies, which have been implemented over the years. Consequently, poor implementation of agricultural policies has resulted in rural and farming communities in the country failing to adapt to the impact of climate change. Ospina and Heeks (2010) argue that adaptation is the act of household, communities, regions, or nation to either tolerate, withstand, resist, or absorb the impact brought on by climate change. Examples of impacts that can be brought by the effect of climate change are food security, livelihoods, human settlement, and water supply (Ospina \& Heeks, 2010).

Climate change is a threat to human societies and natural ecosystems, yet public opinion research finds that public awareness and concern vary greatly (Lee, Markowitz, Howe, Ko, \& Leiserowitz, 2015; Haug, 2016). Shackleton, Ziervogel, Sallu, Gill, and Tschakert (2015) report that to enhance understanding of the process of climate change adaptation and to facilitate the planning and implementation of socially-just adaptation strategies, deeper consideration of the factors that impede adaptation is required. In response, scholars have done much research to identify barriers to adaptation of climate change (Upadhyay \& Bijalwan, 2015). However, despite this progress, knowledge of barriers that hamper adaptation in developing countries remains limited, especially in relation to underlying causes of vulnerability and low adaptive capacity (Mutabazi, George, Dos Santos, \& Felister, 2014; Mutabazi, Amjath-Babu, \& Sieber, 2015). Adaptation goes hand-in-hand with awareness among farmers. One of the approaches used as an awareness technique to deliver climate change adaptation information is the conventional extension service (Tumbo et al., 2015).

The advancements in Information and Communication Technologies (ICTs) have brought a new opportunity for enhancing access to agricultural advisory and extension services (Upadhyay \& Bijalwan, 2015). Empirical evidence from other developing countries like India, South Africa, and Ghana has shown that ICT have enhanced access to and usage of agricultural advisory and extension service (Aker, 2011; George et al., 2011). However, ICTs differ in terms of interactivity; thus, ICT can be categorized into traditional (less interactive) and modern (more interactive). The radio, television and the telephony are traditional ICTs most used in Tanzania (Mtega, 2012). Traditional ICTs are less interactive and in most cases they rarely enhance two-way traffic in the communication process, and when a feedback is made possible, it is not synchronous. Moreover, dissemination of agricultural information to farmers through traditional ICTs is always top-down in nature. Cole and Fernando (2012) describe top-down agricultural 
information dissemination result in an inadequate diagnosis of the difficulties being faced by farmers as the channel used does not facilitate a feedback mechanism. Thus, conventional ICTs are not effective for the provision of agricultural advisory and extension services in some rural areas of Tanzania. Modern ICTs used in Tanzania as mentioned by Sanga, Phillipo, Mlozi, Haug, and Tumbo, (2016) includes Internet, mobile phone applications, and ICT enabled agro-advisory systems. Modern ICTs are more interactive ICTs as they allow more collaboration and provisions for instant feedback from crowd. Studies in Tanzania show that among the modern ICTs, mobile phones are the most used (Mtega \& Malekani, 2009; Mtega, 2012; Sife, Kiondo, \& Lyimo-Macha, 2010; Sanga Phillipo, Mlozi, Haug, \& Tumbo, 2016).

According to the Tanzania Communication Regulatory Authority (TCRA) second quarterly statistics report of 2016, mobile phone infrastructure and the subscriptions to mobile phone services has grown exponentially over the past 10 years (Tanzania Communication Regulatory Authority [TCRA], 2016; TCRA, 2017). This has created an opportunity to use mobile phone services among most of Tanzania from both urban and rural areas. Moreover, TCRA (2016) shows that both the on and off net tariffs have been falling from the year 2005 to 2016 thus making mobile phone services more affordable to the majority in the country. The report showed that subscriptions to mobile networks reached more than 41 million subscriptions registered at the end of June 2017. In this period, more than 3.7 billion text messages (SMS) were used to communicate (TCRA, 2017). This is the evidence why system that supports communication via SMS was opted in this study.

The report ${ }^{i}$ from workshop on Improving Climate Services for Farmers in Africa and South Asia identified challenges that hinder farmers from using climate services in different countriesii. The identified challenges from the report are as follows: traditional climate information is not well documented, there is a lack of accessibility to climate services, there exists ignorance or lack of knowledge on the availability of climate services, an absence of climate education is apparent, climate information not user friendly, there is lack of trust from farmers towards the service providers, at times the type of information is not reliable, there are inconsistencies in the information delivery, climate information is untimely communicated to farmers, channels of communications are not of the same quality depending on who is doing the communicating, when the communication occurs, and by what medium is used; language and technical understanding of the climate forecasts makes it problematic to interpret; there is a failure to analyze the benefits of climate information; there are poor linkages among actors along the value chains (e.g., between seed suppliers and farmers); there is a lack of sufficient capacity to make use of the information; climate information (especially the science-based) is mostly generalized and difficult to localize and access, and understanding of climate information (Tall et al., 2014).

Hence, there is no doubt that there is a need to enhance farmers access to advisory and extension service related to climate change adaptation using a blend of conventional methods, mobile phone applications, and other ICTs (Caine et al., 2015).

\section{Significance of the Research Problem}

Agricultural advisory and extension services in Tanzania are ineffective partly because most of the generated knowledge and information aimed to improve agricultural production do not reach farmers 
(Mkapa, 2005; URT, 2008). Also, farmers in Tanzania argue that the problem is due to lack of capital and labour. Furthermore, farmers cannot afford to take the risk and that farming is not necessarily profitable) (Haug, Hella, Nchimbi-Msolla, Mwaseba, \& Synnevag, 2016; Haug, 2016). In most cases usage of developed agricultural innovations and technologies is limited due to limited number of agricultural extension staff with low access to agricultural information (United Republic of Tanzania [URT] 2011). Yet, there is fast growing ICT infrastructure in Tanzania in both rural and urban areas (TCRA, 2017). Several studies have shown that rural farmers in Tanzania have started using ICTs for accessing various services to support their farming (Sanga, Kalungwizi, \& Msuya, 2013; Sanga, Mlozi, Tumbo, Mussa, Muhiche, \& Haug., 2014; Churi, Mlozi, Mahoo, Tumbo, \& Casmir, 2013; Mtega, 2012; Nyamba \& Mlozi, 2012; Churi, Mlozi, Tumbo, \& Casmir, 2012; Chilimo, 2008; Mtega \& Malekani, 2009; Mushi \& Nduye, 2012; Alhassan \& Kwakwa, 2012). Despite of a number of researches in Tanzania, there are few studies that have been done related to research in developing tools for visualizing data in climate change adaptation (Sanga, Sumari, \& Tumbo, 2013). Even though there is potential of ICT for agriculture in Tanzania, enabling farmers to access agriculture information on climate change adaptation has not been addressed well (Mushi \& Nduye, 2012; Isinika et al., 2016).

Limited access to timely and accurate information has been identified as a major hindrance to enable farmers to get agriculture information on climate change adaptation (Ajayi et al., 2008). The evidence of this fact is that farmers have no reliable way of knowing when to plant their crops due to change of rainfall patterns (Mwalukasa, 2013). As such, farmers plant before it rains, which leads to destruction of seeds in the soil. Under such circumstances, this deprivation on the farmers could be greatly reduced if they had prior information regarding weather conditions. The forecast of weather need to be done using sophisticated technology since the rain patterns have changed and that the small rainy season has more or less disappeared in some placed (Haug, 2016).

In the light of the above, the Government of Tanzania has taken a number of steps to come up with different ICTs tools, including radio and television, through which farmers could access agricultural knowledge and information (Lwoga, 2010; Mushi \& Nduye, 2012). However, there are some drawbacks with regard to the effectiveness of these tools in disseminating and communing climate change adaptation information. First, the broadcast media, such as television and radio, are expensive and most farmers cannot afford to buy them. Second, timing of the information is another problem. To access the information, farmers have to be listening or watching at the same time the programme is broadcasting (Mntambo, 2007). Hence, farmers are adopting mobile phones to access agricultural information which are cost effective, accessible, and cheap (Sanga, Mlozi, Haug, \& Tumbo, 2016). Despite the fact that mobile phones-based applications are mostly used to enhance agricultural extension service but have brought a new challenge (Wyche \& Steinfield, 2016). This challenge is caused by massive data which are generated (Keim, Kohlhammer, Ellis, \& Mansmann, 2010). Thus, the massive data generated call for a need of developing a tool for data visualization. The aim is at helping farmers and other actors to make informed decision out of the user generated massive data. Content analysis using word or content cloud has been studied by many researchers (McNaught \& Lam, 2010; Cidell, 2010) but its applicability in analysing massive (or big data) generated in ICT based agro-advisory service systems (with content in Swahili) is not adequately researched. This is the research gap which this study seeks to fill. Thus, the goal 
of this paper is to evaluate information seeking behaviour / patterns of farmers who used UshauriKilimo for more than two years in consulting for advisories related to climate change adaptation.

This study tried to answer the following research questions:

1. What are the information needs of farmers in Tanzania who are using UshauriKilimo in advisory information related to climate change adaptation?

2. What are the information seeking behaviors of farmers in Tanzania who are using UshauriKilimo in advisory information related to climate change adaptation?

\section{Research Methodology}

\section{Description of the Study Sites}

The study was conducted in Kilosa District. Kilosa District has good ICTs infrastructure which enable access and use of mobile phones on various uses. Also, this District has been chosen due to high agricultural produce and high arable land for cultivation. In addition, the District is experiencing effect of climate change (Paavola, 2008; Mutabazi et al., 2014; Mutabazi et al., 2015).

\section{Research Design}

The research adopted the qualitative research method. Specifically, content analysis was used to analyse the qualitative data which is found on UshauriKilimo server.

\section{Case Study of Ushaurikilimo}

UshauriKilimo was developed through participatory action research method (Sanga, Phillipo, Mlozi, Haug, \& Tumbo, 2016). It allows farmers and other actors to use their mobile phones to access agricultural information from researchers and extension workers (Sanga, Mlozi, Haug, \& Tumbo, 2016). The agricultural information consists of different categories of information needed by farmers, including information related to adaptation of climate change. The stakeholders/actors who are using UshauriKilimo have been given capacity building for more than two years. The capacity building and empowerment activities were done through training and workshops. Also, there were visits by farmers from Dodoma Municipal in Dodoma and Kilolo District in Iringa to Kilosa farmers in Morogoro. Currently, there are more than 700 farmers who are using UshauriKilimo. The farmers who are using UshauriKilimo are producing massive data (i.e., big data) relating to different topics in agriculture including climate change. 


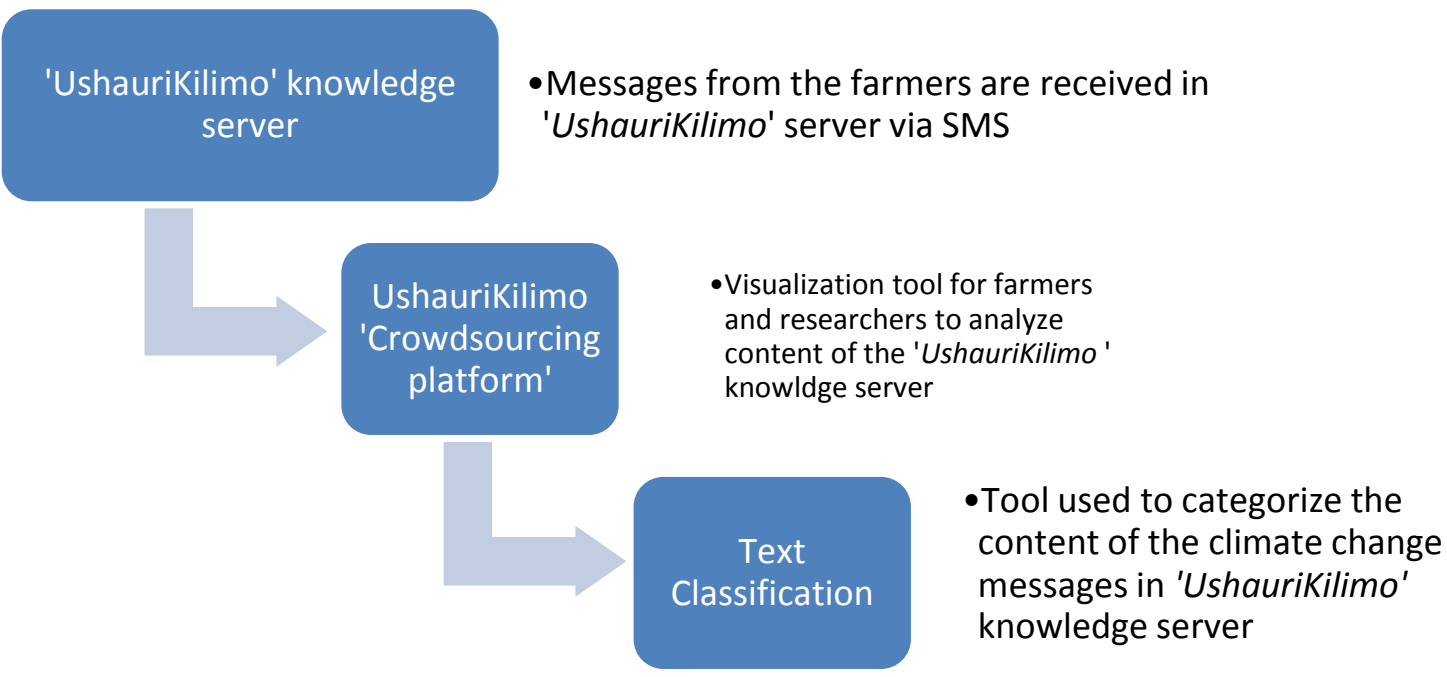

Figure 1. Data analysis process.

UshauriKilimo is a crowdsourcing platform which allows farmers and other actors (i.e., crowd) to engage in all phases of research process (Sanga, Phillipo, Mlozi, Haug, \& Tumbo, 2016). This act of engaging farmers and other actors in scientific investigation is called citizen science. Citizen science refers to the engagement of farmers and other actors (i.e., non-professional volunteers) in scientific investigations (i.e., by asking questions for needs, requirements assessment, or collecting data; developing software, evaluation of software, using the software, or interpreting results (Newman et al., 2012).

\section{Data Analysis}

After massive data had been deposited in a crowdsourcing platform, the data mining tool was developed to help farmers search information using different keywords. The tool fetched data from the UshauriKilimo knowledge server (Figure 1). The results from the search were further subjected to data cleaning. The cleaned data were extracted to the data mining tool. The aim of this process was for recognizing a pattern of most frequent words (i.e., word visualization) from the corpus of a crowdsourcing platform.

In order to harvest data for this study, data from UshauriKilimo with keywords, such as climate or weather, were searched. Since the data in UshauriKilimo was in Swahili, the keyword that was used during searching was "hali ya hewa" (Table 1). After that had been collected, the data were analysed using a mixed methods approach (i.e., manual content analysis method and automated text classification, such as semi-automatic text classification). 
Table 1

Data Collection and Analysis

\begin{tabular}{|l|l|l|c|}
\hline $\begin{array}{l}\text { Research } \\
\text { approach }\end{array}$ & Type of data & $\begin{array}{c}\text { Data } \\
\text { analysis }\end{array}$ \\
\hline Qualitative & $\begin{array}{l}\text { data found on } \\
\text { www.ushaurikilimo.org }\end{array}$ & $\begin{array}{l}\text { Questions and answers from farmers, extension } \\
\text { agents, and other actors in the value chain } \\
\text { related to climate change issues }\end{array}$ & $\begin{array}{l}\text { Content } \\
\text { analysis }\end{array}$ \\
\hline
\end{tabular}

\section{Results and Discussion}

A simple search in a crowdsourcing platform using the keyword "hali ya hewa" (Swahili word for weather and climate), 22 questions and answers were obtained (Figure 2).

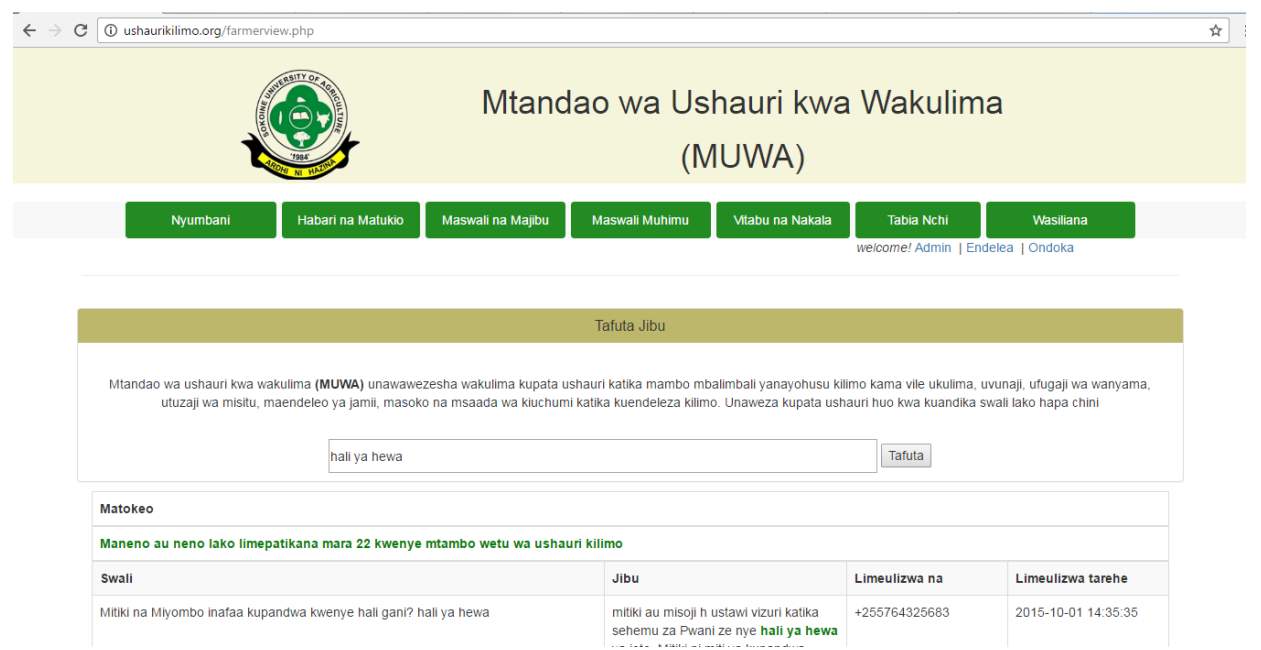

Figure 2. Search interface for the system.

Then all 22 statements containing questions and answers were cleaned to remove mobile phone numbers of farmers who asked questions and the dates when the questions were asked. After this data cleaning process, 1148 words were extracted (Figure 3 ). 


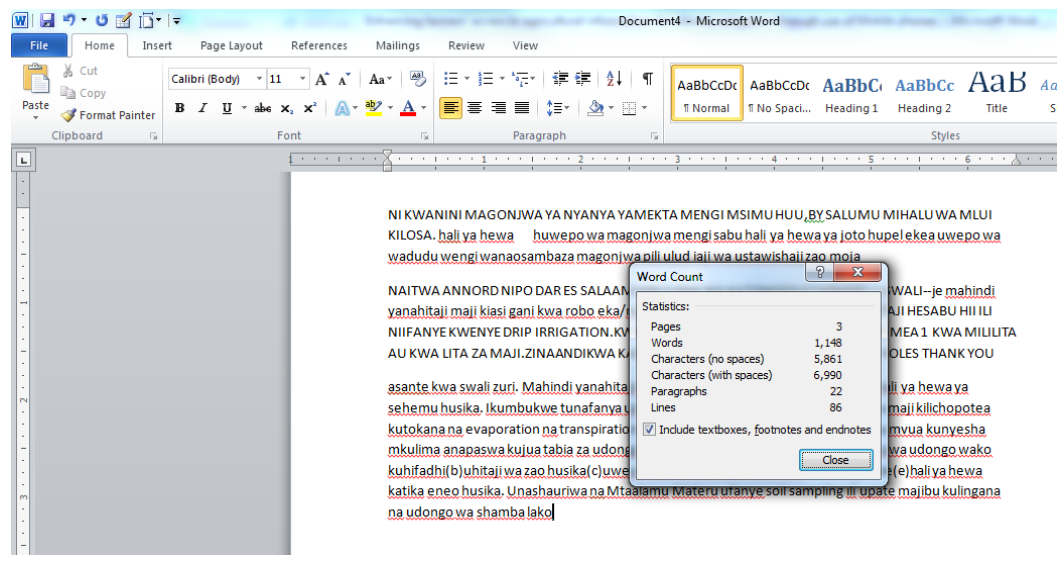

Figure 3. Data cleaning of the results from simple search.

The 1148 words obtained were entered or superimposed in a web-based word or text visualization system or word cloud (www.wordle.net).

\section{Limitations of Study}

This study has some limitations which need to be noted. According to Zhu, Rodríguez-Hidalgo, Questier, and Torres-Alfonso (2015) the study which deals with analysis of texts has limitations in terms of the following factors, namely: sample size, contextualized environment of the study, and Hawthorne effect. With respect to these factors, the study sample size was small and limited to 22 farmers who asked advisories related to "climate change." Secondly, the result of this study is applied to a specific setting and thus, cannot be generalized. Lastly, the results might be related to the so-called Hawthorne effect as the respondents who are either farmers, extension agents, and researchers were introduced to new method of agro-advisory system using ICT. This system was used to complement a conventional agricultural extension system and was not used on its own.

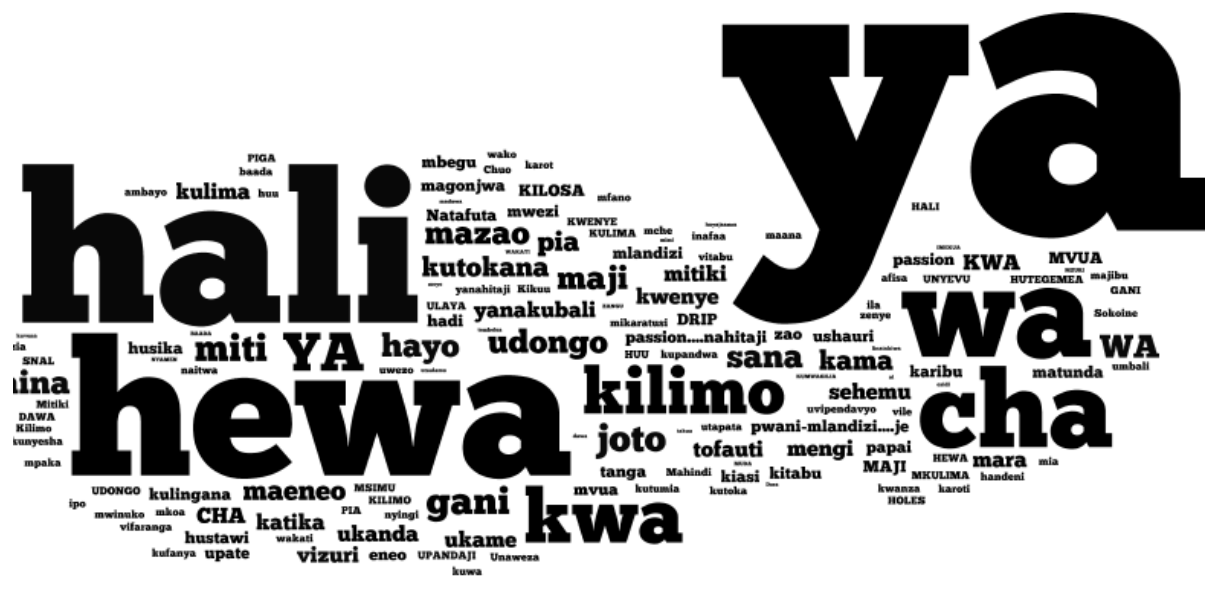

Figure 4. Word cloud after analysis using Wordle.

Words which appear most in the 22 frequently asked questions were: climate, weather, agriculture, soil, water, teak, forestry, rain, drip irrigation, hot temperature, crops, passion, and advisory (Figure 4). The 
words like "mazao ya ukame" (drought tolerant varieties) means farmers are aware of elements of climate smart agriculture ("kilimo hifadhi") which include use of drought resistant varieties and crops. Also, the word "drip," which mean use of drip irrigation, is highly recommended for climate smart agriculture. As well, the other frequently used words like "mitiki," which means teak trees, are recommended to conserve soil ("udongo") and water ("maji") so as to sustain smallholder farmers livelihoods (Lacombe, Bolliger, Harrison, \& Ha., 2016) were found in word cloud.

With the Wordle analysis, it is not easy to determine the frequency of appearance for each word asked by farmers. Thus, we opted to subject analyse the same texts using a different tool for analysis called "TagCrowd." The results after the analysis using TagCrowd is as depicted in Figure 5.

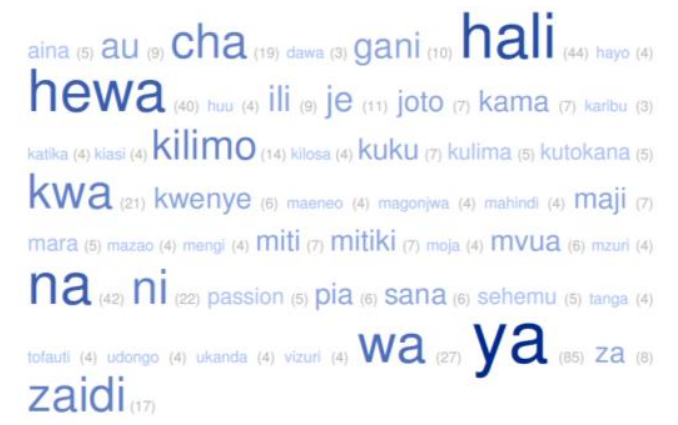

Figure 5. Word cloud after analysis using TagCrowd.

After triangulation of analysis using two word visualization tools, researchers concluded that the most frequent keywords obtained from TagCrowd almost resemble those which were obtained using the Wordle analysis tool (Figure 4, Figure 5). The keywords obtained from TagCrowd tool are: climate, weather, agriculture, soil, water, teak, forestry, rain, drip irrigation, hot temperature, crops, passion, and advisory. These keywords point to the impact of climate change. This is supported by previous literature from a study area which showed that there is impact experienced by farmers due to climate change. Mayala et al. (2015) argue that farmers in Kilosa indicated that there is change of rainfall pattern and resulted to insufficient food and rise in temperature (Isinika et al., 2016). Even though Kilosa District is experiencing the effects of climate change, a study by Mayala et al. (2015) found that farmers in Kilosa have little knowledge on climate change because one in four understand the word "mabadiliko ya tabia nchi," a Swahili word for climate change.

When we searched UshauriKilimo using keyword "mabadiliko ya tabia," we found 4 results. Three farmers asked about the type of crops which they can grow well under limited rainfall. The fourth farmer asked about "why wild animals from Mikumi National Park invade their crops? Is it because of climate change?"

Results from this study show that even though mobile and web-based agro-advisory service systems, after being in use for two years, produced bulk data, evaluating the pattern of data (in terms of words and texts) from its database is a difficult process (Figure 2, Figure 3, Figure 4, Figure 5). Different researchers have used various qualitative and quantitative data analysis techniques, such as concept mapping, social networks analysis, and content analysis using word visualization tools (Zhu et al., 2015; Cho \& Tobias, 
2009; Berlanga, Van Rosmalen, Boshuizen, \& Sloep, 2012). In our case study, we developed a decision support system (DSS) for data visualization. Also, data visualization was done using Wordle and TagCrowd tools. Furthermore, Statistical Package for Social Sciences (SPSS) was used to do additional analysis. This was done by compiling SPSS template with the data related to climate/weather, drought, and irrigation keywords in the questions asked by farmers using their mobile phones. The key words "Hali ya hewa," "ukame," and "umwagiliaji” were used to capture questions on climate change asked by farmers. There were 38 questions and answers related to these three keywords. Table 2 shows the date when the questions were asked, frequency, percentage, and the cumulative frequency (Table 2).

Table 2

Frequency of Questions Asked With Either Climate/Weather, Drought, or Irrigation Keywords

\begin{tabular}{|c|c|c|c|c|}
\hline & & Frequency & Percent & Cumulative percent \\
\hline \multirow[t]{20}{*}{ Valid } & 2015-05-09Т00:00:00.000 & 1 & 2.6 & 2.6 \\
\hline & 2015-05-25T00:00:00.000 & 1 & 2.6 & 5.3 \\
\hline & 2015-06-07T00:00:00.000 & 1 & 2.6 & 7.9 \\
\hline & 2015-07-06T00:00:00.000 & 1 & 2.6 & 10.5 \\
\hline & 2015-07-08T00:00:00.000 & 1 & 2.6 & 13.2 \\
\hline & 2015-07-11T00:00:00.000 & 1 & 2.6 & 15.8 \\
\hline & 2015-07-21T00:00:00.000 & 1 & 2.6 & 18.4 \\
\hline & 2015-08-06T00:00:00.000 & 1 & 2.6 & 21.1 \\
\hline & 2015-08-09T00:00:00.000 & 1 & 2.6 & 23.7 \\
\hline & 2015-08-10T00:00:00.000 & 1 & 2.6 & 26.3 \\
\hline & 2015-08-14T00:00:00.000 & 1 & 2.6 & 28.9 \\
\hline & 2015-08-26T00:00:00.000 & 1 & 2.6 & 31.6 \\
\hline & 2015-09-11T00:00:00.000 & 2 & 5.3 & 36.8 \\
\hline & 2015-09-13T00:00:00.000 & 1 & 2.6 & 39.5 \\
\hline & 2015-09-29T00:00:00.000 & 1 & 2.6 & 42.1 \\
\hline & 2015-10-01T00:00:00.000 & 1 & 2.6 & 44.7 \\
\hline & 2015-10-08T00:00:00.000 & 1 & 2.6 & 47.4 \\
\hline & 2015-11-01T00:00:00.000 & 1 & 2.6 & 50.0 \\
\hline & 2016-02-13T00:00:00.000 & 1 & 2.6 & 52.6 \\
\hline & 2016-02-18T00:00:00.000 & 1 & 2.6 & 55.3 \\
\hline
\end{tabular}




\begin{tabular}{|c|c|c|c|}
\hline 2016-02-19Т00:00:00.000 & 1 & 2.6 & 57.9 \\
\hline 2016-04-27T00:00:00.000 & 1 & 2.6 & 60.5 \\
\hline 2016-04-28T00:00:00.000 & 1 & 2.6 & 63.2 \\
\hline 2016-05-02T00:00:00.000 & 1 & 2.6 & 65.8 \\
\hline 2016-05-12T00:00:00.000 & 1 & 2.6 & 68.4 \\
\hline 2016-05-25T00:00:00.000 & 1 & 2.6 & 71.1 \\
\hline 2016-06-08T00:00:00.000 & 1 & 2.6 & 73.7 \\
\hline 2016-06-27T00:00:00.000 & 1 & 2.6 & 76.3 \\
\hline 2016-07-05T00:00:00.000 & 1 & 2.6 & 78.9 \\
\hline 2016-08-03T00:00:00.000 & 2 & 5.3 & 84.2 \\
\hline 2016-09-09T00:00:00.000 & 1 & 2.6 & 86.8 \\
\hline 2016-10-05T00:00:00.000 & 2 & 5.3 & 92.1 \\
\hline 2016-10-12T00:00:00.000 & 1 & 2.6 & 94.7 \\
\hline 2016-10-26T00:00:00.000 & 1 & 2.6 & 97.4 \\
\hline 2016-11-01T00:00:00.000 & 1 & 2.6 & 100.0 \\
\hline Total & 38 & 100.0 & \\
\hline
\end{tabular}

Table 2 shows that farmers asked many questions between June and November of each year (i.e., 2015 and 2016). Also, Table 2 shows that even though farmers have been asking questions relating to other problems in agriculture, issues concerning climate change are also included (Sanga, Phillipo, Mlozi, Haug, \& Tumbo, 2016). In total, there are 1739 questions in UshauriKilimo (Fue et al., 2017). Data from UshauriKilimo indicate that the questions, which came from farmers asking about other issues and not those related to climate change, totalled 1701 questions. There were 605 questions and answers related to livestock husbandry (Fue et al., 2017), and 63 questions and answers related to markets and market information, posted on UshauriKilimo. Furthermore, there were 427 questions and answers related to forestry information. This means that questions and answers related to crops totalled 605. Figure 6 shows how farmers perceive climate change to be in regards to other challenges they are facing (e.g., marketing, prices, inputs, etc.). 


\begin{tabular}{|l|l|l|}
\hline Type of information need & Number of questions and answers & Percentage \\
\hline Climate change & 22 & 1.27 \\
\hline Livestock husbandry & 605 & 34.79 \\
\hline Markets / market information & 63 & 3.62 \\
\hline Forestry & 427 & 24.55 \\
\hline Crop farming & 622 & 35.77 \\
\hline Total & 1739 & 100 \\
\hline
\end{tabular}

Figure 6. General information needs and seeking behaviour of farmers using Ushaurikilimo.

Thus, UshauriKilimo is linking farmers, researchers, and extension agents for communication of agriculture information related to a number of topics including climate change (Sanga, Mlozi, Haug, \& Tumbo, 2016). Not all farmers in Kilosa District are aware of Ushaurikilimo, a system that can help in information sharing in climate change issues. Climate change is a great threat to agricultural production in Tanzania and there is a need to scale up this system so that its potential can benefit a large number of farmers and other actors. Since only 22 questions out of 1739 asked were related to climate change, this means that most of the farmers are unaware of climate change. Awareness programs are required to sensitize farmers on information related to climate change adaptation. Also, climate change adaptation information is required to cope with climate change (Haug, 2012; Haug, 2016). Milder, Majanen, and Scherr (2016) found that despite the environmental, economic, and social benefits to climate change adaptation techniques, adoption was sparse. They recommended that in order to facilitate the adoption of climate change adaptation information, there is a need for intensive education, policy changes, and infrastructure development (Nambiza, 2014). These suggestions concur with Elia, Mutula, and Stilwell (2015) who advocated for repackaging of current and accurate information on climate change and variability, farmer education and training, collaboration between researchers, meteorology experts, extension officers and farmers, as well as formulation of a framework for the dissemination of information related to climate change adaptation. In this respect, UshauriKilimo has been successfully used to disseminate extension services to more than 700 farmers in Tanzania via mobile phones and the web (Sanga, Phillipo, Mlozi, Haug, \& Tumbo, 2016). There are more than 1300 questions and answers that have been given to farmers by extension agents. Among the advisories given in UshauriKilimo, the different coping strategies for climate change adaptation include, use of drought resistant varieties for maize, use of sacks for post-harvest storage, use of drip irrigation, adjusting planting dates, and early warning communication system for planting dates and weather forecast. These coping strategies have also been advocated in other countries, such as Ethiopia, which have been experiencing effects of climate change (Mengistu, 2011; Ospina \& Heeks, 2011). Mengistu (2011) argues that there is need for early warning system to disseminate climate change coping strategies to farmers and other actors. Such systems will complement the indigenous knowledge that is already being in used by farmers in developing countries (Elia, Mutula, \& Stilwell, 2014). 
Furthermore, findings show that UshauriKilimo is offering advisories to farmers who seek information related to climate change adaptation. The information seeking behaviour of farmers ranges from using improved seed, mulching, intercropping, as well as doing various on farm practices like keeping local chicken, bee keeping, and aquaculture (i.e., integrated agriculture). Also, crop diversification is being practiced by farmers and this has helped to increase farmers' yields and replenishing soil nutrients. In addition, farmers are adopting drought tolerant crops (e.g., cassava, maize, sorghum, and millet). Home gardens, kitchen gardens, or sack gardens are also been practiced in Kilosa District. Furthermore, system of rice intensification technology that uses a minimal amount of water is being practiced by a few farmers in Kilosa. These findings concur with earlier studies that were done in Kilosa (Paavola, 2008; Mutabazi et al., 2014,).

Furthermore, farmers sought information about floods after it has occurred in 2016. The extension agent advised the farmer to farm crops that can yield in short periods of time (Figure 7).

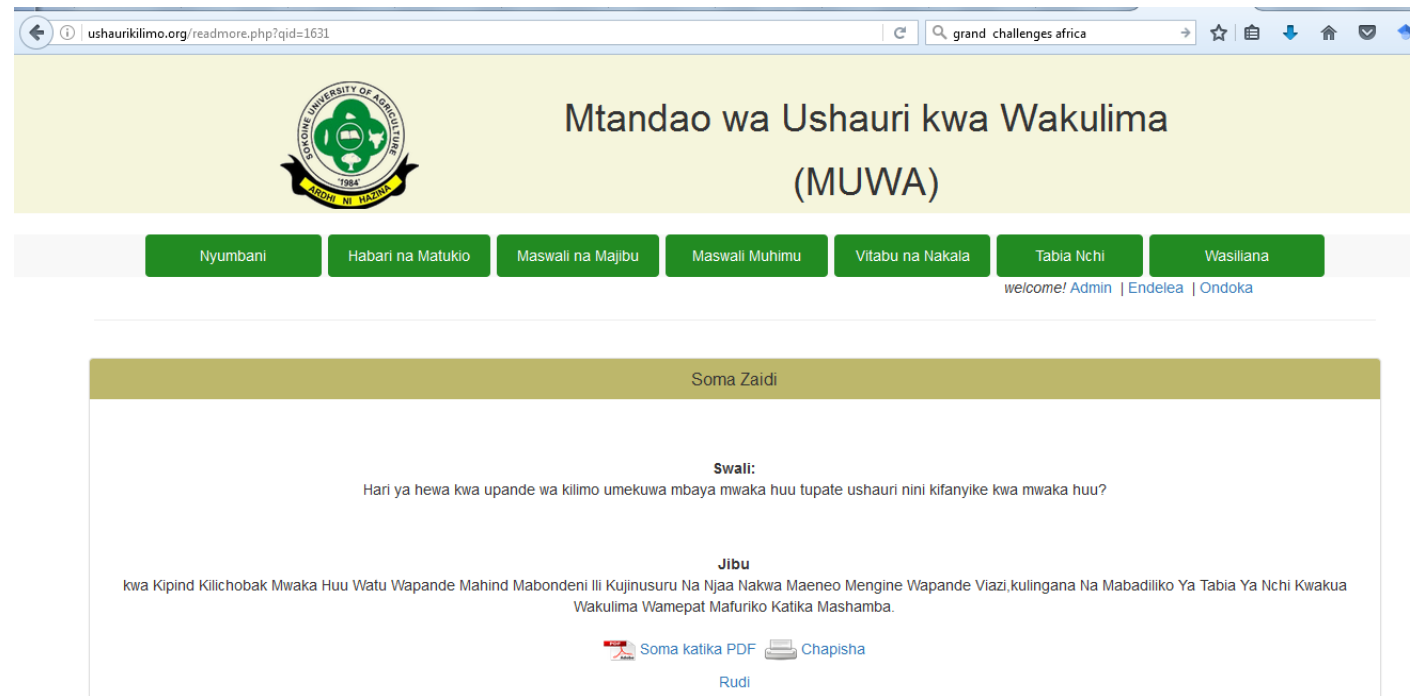

Figure 7. Advice from extension agent about what to farm after flooding has occurred in Kilosa.

The results reported in this study showed that farmers identify problems while they were doing different agriculture activities and then extension agents and researchers gain awareness of those problems troubling farmers resulting in the establishment of a dialogue via mobile phones (i.e., UshauriKilimo). The purpose was for extension agents and researchers to influence behavioural change of farmers with respect to climate change adaptation strategies (Harvey et al., 2012). This was achieved through a participatory action research approach (PARA) in a multiple loop of learning to obtain the intended outcomes (Armitage, Marschke, \& Plummer, 2008). Therefore, this study responds to the recommendation made by Mushi and Nduye (2012) who advocated the need for implementation of an early warning system to share issues related to climate change. 


\section{Conclusion}

Previous studies indicate that farmers in Kilosa District are experiencing delayed onset of rains, poor rainfall distribution over the cropping season, and extreme weather conditions, such as droughts and floods (Paavola, 2008; Mutabazi et al., 2014,). These effects of climate changes, affect farmers in their farming activities. Most farmers in the Kilosa District have limited access to technologies, resources, and extension services. Thus, these challenges leave these farmers more vulnerable to climate change than those with more resources. Despite these challenges, agricultural activities remain the main source of livelihood for smallholder farmers in Kilosa District. The conventional way of using extension agents, on which farmers largely depend on, is no longer sufficient to help farmers obtain information related to climate change adaptation. The aim of developing UshauriKilimo was to link farmers, researchers, and extension agents in communicating agricultural information and knowledge (Sanga, Mlozi, Haug, \& Tumbo, 2016). From this study, we have found that farmers share agriculture information related to coping strategies for climate change adaptation. Already, massive data is being deposited into the UshauriKilimo database. This study presents results from the data visualization tool, which was used in determining the pattern of information seeking behaviour of farmers in relation to climate change adaptation. The findings from the developed data visualization tool were compared to the results obtained from the content analysis, Wordle and TagCrowd tools. Furthermore, the results from Wordle and TagCrowd tools were compared to the results from an analysis done using Statistical Package for the Social Sciences (SPSS).

One may ask "Does the information seeking behaviour of farmers differ when it comes to acquiring climate change adaptation information compared to acquiring other types of farming related information?" From this study finding, one can deduce that farmers asked how to mitigate impacts of climate change after it had occurred. This is different compared to the information seeking behaviour of farmers in other types of farming (Sanga, Phillipo, Mlozi, Haug, \& Tumbo, 2016; Fue et al., 2017). Also, this study indicates that farmers seek information about climate change adaptation from not only farmers' friends and neighbours, extension agents, TV, radio, mobile phones, and mass and print media, but also from other sources of information like the Internet, web, and mobile apps. This blended way of provision of extension services is different from earlier studies (Mwalukasa, 2013). This paper has shown that UshauriKilimo supported the demand-led and personalized/client-based extension service in order to meet the farmers' needs in seeking information related to climate change adaptation. We have shown new ways to communicate climate change adaptation information which is different from the supply driven and top-down approach that is being done by many organizations ${ }^{\text {iii. }}$.

The authors recommend a future study on determining the pattern of information from UshauriKilimo using an artificial intelligence algorithm for text classification. 


\section{Reference}

Ajayi, O.C., Akinnifesi, F.K., Sileshi, G., Chakeredza, S., Mn'gomba, S., Ajayi, O. \& Chineke, T. (2008). Local solutions to global problems: The potential of agroforestry for climate change adaptation and mitigation in southern Africa. In TroFCCA regional meeting 'knowledge and action on forests for climate change adaptation in Africa (pp.1-17). Accra, Ghana.

Aker, J. C. (2010). Dial “A” for agriculture: using information and communication technologies for agricultural extension in developing countries. Tuft University, Economics Department and Fletcher School, Medford MAO2155, 37. Retrieved from http://cega.berkeley.edu/assets/cega events/30/AfDR Aker Dial-A-for-Agriculture P-S.pdf

Alhassan, H., \& Kwakwa, P. A. (2012). The use of mobile phones by small scale farmers in Northern Ghana: Benefits and challenges. Journal of Entrepreneurship and Management, 1(3), 4045. Retrieved from http://proxyremote.galib.uga.edu:80/login?url=https://search.proquest.com/docview/1478021620?accounti $\underline{\mathrm{d}=14537}$

Armitage, D., Marschke, M., \& Plummer, R. (2008). Adaptive co-management and the paradox of learning. Global Environmental Change, 18(1), 86-98. doi: 10.1016/j.gloenvcha.2007.07.002

Berlanga, A. J., Van Rosmalen, P., Boshuizen, H. P., \& Sloep, P. B. (2012). Exploring formative feedback on textual assignments with the help of automatically created visual representations. Journal of Computer Assisted Learning, 28(2), 146-160. Retrieved from https://dspace.ou.nl/bitstream/1820/2961/6/Berlangaetal-JCAL-DSpace.pdf

Caine, A., Dorward, P., Clarkson, G., Evans, N., Canales, C., \& Stern, D. (2015). Review of mobile applications that involve the use of weather and climate information: Their use and potential for smallholder farmers (CCAFS Working Paper No.15O). Copenhagen, Denmark: CGIAR Research Program on Climate Change, Agriculture and Food Security (CCAFS). Retrieved from http://hdl.handle.net/10568/69496

Chilimo, W. (2008). Information and communication technologies and sustainable livelihoods: A case of selected rural areas of Tanzania (Unpublished doctoral thesis). University of KwaZulu-Natal, Pietermaritzburg, South Africa. Retrieved from http://elibrary.pu.ac.ke/ir/handle/123456789/468

Cho, K. M., \& Tobias, D. (2009). Applying the concept mapping methodology. Cornell University. Retrieved from http://pdf.usaid.gov/pdf docs/PAooHSSF.pdf

Churi, A. J., Mlozi, M. R., Mahoo, H., Tumbo, S. D., \& Casmir, R. (2013). A decision support system for enhancing crop productivity of smallholder farmers in semi-arid agriculture. International Journal of Information and Communication Technology Research, 3(8), 238-248. Retrieved from http://bestdialogue.antenna.nl/jspui/bitstream/20.500.12018/2712/1/10.1.1.412.557.pdf 
Churi, A. J., Mlozi, M. R., Tumbo, S. D., \& Casmir, R. (2012). Understanding farmers' information communication strategies for managing climate risks in rural semi-arid areas, Tanzania. International Journal of Information and Communication Technology Research, 2(11), 838 845. Retrieved from http://esjournals.org/journaloftechnology/archive/vol2no11/vol2no11 6.pdf

Cidell, J. (2010). Content clouds as exploratory qualitative data analysis. Area, 42(4), 514-523. doi: $10.1111 / \mathrm{j} .1475-4762.2010 .00952$

Cole, S. A., \& Fernando, A. N. (2012). The value of advice: Evidence from mobile phone-based agricultural extension (Working Paper No. 13-047). Cambridge: Harvard Business School. Retrieved from http://siteresources.worldbank.org/INTPOVRES/Resources/Cole Paper 23Oct13.pdf

Eicher, C. (2003, December). Flashback: Fifty years of donor aid to African agriculture. Paper presented at the International Policy Conference on successes in African Agriculture: Building for the Future, Pretoria, South Africa. Retrieved from https://vtechworks.lib.vt.edu/handle/10919/66107

Elia, E. F., Mutula, S., \& Stilwell, C. (2014). Use of Indigenous knowledge in seasonal weather forecasting in semi-arid central Tanzania. South African Journal of Libraries and Information Science, 8O(1), 18-27. Retrieved from http://sajlis.journals.ac.za/pub/article/view/1395/1312

Elia, E., Stilwell, C., \& Mutula, S. (2015). Disseminating and using information on climate change and variability: A case study of farmers in Maluga and Chibela villages in central Tanzania. Mousaion, 33(3), 1-24. Retrieved from http://journals.co.za/content/mousaion/33/3/EJC184572

Fue, K., Geoffrey, A., Mlozi, M. R. S., Tumbo, S.D., Haug, R., \& Sanga, C. A. (2017). Analyzing usage of crowdsourcing platform 'Uushaurikilimo' by pastoral and agro-pastoral communities in Tanzania, International Journal of Instructional Technology and Distance Learning, 13(12), 3-22. Retrieved from http://www.suaire.suanet.ac.tz:8080/xmlui/handle/123456789/1280

George, T., Bagazonzya, H., Ballantyne, P., Belden, C., Birner, R., Del Castello, R., \& Treinen, S. (2011). ICT in agriculture: Connecting smallholders to knowledge, networks, and institutions. Washington, DC: World Bank. Retrieved from https://openknowledge.worldbank.org/handle/10986/12613

Harvey, B., Ensor, J., Carlile, L., Garside, B., Patterson, Z., \& Naess, L.O. (2012). Climate change communication and social learning-Review and strategy development for CCAFS (CCAFS Working Paper No. 22). CGIAR Research Program on Climate Change, Agriculture and Food Security (CCAFS), Copenhagen, Denmark. Retrieved from www.ccafs.cgiar.org/handle/10568/24456

Haug, R. (2012). Climate smart and women smart Agriculture: Food security in the time of climate change. FOKUS, 1, 26-27. 
Haug, R. (2016). From Ujamaa to big results now: Sustainable transformation of Tanzanian agriculture in the frame of climate change. In R. Lal, D. Kraybill, D. O. Hansen, B. R. Singh., T. Mosogoya, \& L. O. Eik (Eds.), Climate change and multi-dimensional sustainability in African agriculture (pp. 467-482). Berlin, Germany: Springer International Publishing.

Haug, R. \& Hella, J. (2013). The art of balancing food security: securing availability and affordability of food in Tanzania. Food Security, 5(3), 415-426. doi: 10.1007/s12571-013-0266-8

Haug, R., Hella, J. P., Nchimbi-Msolla, S., Mwaseba, D. L., \& Synnevag, G. (2016). If technology is the answer, what does it take? Development in Practice, 26(3), 375-386.

doi:10.1080/09614524.2016.1151478

Havnevik, K., Bryceson, D., Birgegård, L. E., Matondi, P., \& Beyene, A. (2007). African agriculture and the World Bank: Development or impoverishment? Retrieved from https://www.divaportal.org/smash/get/diva2:275867/FULLTEXTo1.pdf

Isinika, A., Hella, J., \& Moshi, A. (2016). Climate variability and farm technology adoption decisions among smallholder farmers in Pangani river basin. Journal of Economics and Sustainable Development, 7(2), 18-24. Retrieved from http://iiste.org/Journals/index.php/JEDS/article/view/28436

Keim, D. A., Kohlhammer, J., Ellis, G., \& Mansmann, F. (2010). Mastering the information age-solving problems with visual analytics. Goslar, Germany: Eurographics Association.

Lacombe, G., Bolliger, A., Harrison, R., \& Ha, T. T. T. (2016). Integrated tree, crop and livestock technologies to conserve soil and water, and sustain smallholder farmers' livelihoods in Southeast Asian uplands. In L. Hiwasaki, L. Bolliger, G. Lacombe, J. Raneri, M. Schut, \& S. Staal (Eds.). Integrated systems research for sustainable smallholder agriculture in the Central Mekong: Achievements and challenges of implementing integrated systems research (pp. 41-64). Hanoi, Vietnam: World Agroforestry Centre. Retrieved from http://hdl.handle.net/10568/78362

Lee, T. M., Markowitz, E. M., Howe, P. D., Ko, C. Y., \& Leiserowitz, A. A. (2015). Predictors of public climate change awareness and risk perception around the world. Nature Climate Change, 5(11), 1014-1020. doi:10.1038/nclimate2728

Lwoga, E. T. (2010). Bridging the agricultural knowledge and information divide: The case of selected telecenters and rural radio in Tanzania. The Electronic Journal of Information Systems in Developing Countries, 43(1),1-14. doi: 10.1002/j.1681-4835.2010.tboo310.x

Lwoga, T., Stilwell, C., \& Ngulube, P. (2011). Access and use of agricultural information and knowledge in Tanzania. Library Review, 6o(5), 383-395. doi: 10.1108/o0242531111135263

Mayala, B. K., Fahey, C. A., Wei, D., Zinga, M. M., Bwana, V. M., Mlacha, T., Rumisha, S. F. ... \& Mboera, L. E. (2015). Knowledge, perception and practices about malaria, climate change, livelihoods and 
food security among rural communities of central Tanzania. Infectious Diseases of Poverty, 4(21), 1-9 1. doi:10.1186/s40249-015-0052-2

McNaught, C., \& Lam, P. (2010). Using Wordle as a supplementary research tool. The Qualitative Report, 15(3), 630-643. Retrieved from https://nsuworks.nova.edu/tqr/vol15/iss3/8

Mengistu, D. (2011). Farmers' perception and knowledge on climate change and their coping strategies to the related hazards: case study from Adiha, central Tigray, Ethiopia. Agricultural Sciences, 2, 138-145. doi: 10.4236/as.2011.22020.

Milder, J. C., Majanen, T., \& Scherr, S. J. (2016). Performance and potential of conservation agriculture for climate change adaptation and mitigation in Sub-Saharan Africa. Retrieved from http://assets.panda.org/downloads/2011 climate and agriculture in ssa 1.pdf

Mkapa, B.W. (2005). Towards agriculture-led growth in Tanzania: Policies, priorities and strategies. Dar es Salaam, Government Printer.

Mntambo, B. D. (2007). Socio-Economic, Institutional and Behavioural Determinants of Accessibility and Utilization of Agricultural Information by Women Farmers in Korogwe (Unpublished master's thesis). Sokoine University of Agriculture, Morogoro, Tanzania.

Morris, C. (2005). The role of computers and information technology in rural agricultural information systems. Retrieved from http://www.hs.unp.ac.za/im/morris2.pdf

Mtega, W. P. (2012). Access to and usage of information among rural communities: A case study of Kilosa District Morogoro Region in Tanzania. Partnership. The Canadian Journal of Library and Information Practice and Research, $7(1), 1-12$. Retrieved from https://journal.lib.uoguelph.ca/index.php/perj/article/view/1646/2462\#.Wtz1P3WUuDc

Mtega, W. P., \& Malekani, A. W. (2009). Analysing the usage patterns and challenges of telecenters among rural communities: experience from four selected telecentres in Tanzania. International Journal of Education and Education using ICTs (IJEDICT), 5(2), 68-87. Retrieved from http://proxyremote.galib.uga.edu:80/login?url=https://search.proquest.com/docview/869069787?accountid $=14537$

Mushi, R. T., \& Nduye, G. E. (2012). The role of information communication and technologies (ICTs) in addressing climate change challenges in Tanzania. Journal of Gender, Information and Development in Africa (JGIDA), 1(1), 29-41. Retrieved from http://hdl.handle.net/10520/EJC128631

Mutabazi, K. D., Amjath-Babu, T. S., \& Sieber, S. (2015). Influence of livelihood resources on adaptive strategies to enhance climatic resilience of farm households in Morogoro, Tanzania: an indicator- 
based analysis. Regional Environmental Change, 15(7), 1259-1268. doi: 10.1007/s10113-0150800-7

Mutabazi, K. D., George, C. K., Dos Santos, A. S., \& Felister, M. M. (2014). Livelihood implications of REDD+ and costs-benefits of agricultural intensification in REDD+ pilot area of Kilosa, Tanzania. Journal of Ecosystem \& Ecography, 4(2), 1-11. doi: 10.4172/2157-7625.1000144

Mwalukasa, N. (2013). Agricultural information sources used for climate change adaptation in Tanzania. Library Review, 62(4/5), 266-292. doi: 10.1108/LR-12-2011-0096

Mwandosya, M. J., Nyenzi, B. S., \& Lubanga, M. L. (1998). The assessment of vulnerability and adaptation to climate change impacts in Tanzania. Centre for Energy, Environment, Science and Technology. Retrieved from https://www.cabdirect.org/cabdirect/abstract/20016786277

Nambiza, W. (2014). Understandings of climate change, climate-smart small scale agriculture and practices of climate-smart small scale agriculture as climate change adaptation in two Tanzanian districts: a case study of Kilosa and Chamwino districts. Retrieved from http://41.73.194.134:8080/xmlui/handle/123456789/448

Newman, G., Wiggins, A., Crall, A., Graham, E., Newman, S., \& Crowston, K. (2012). The future of citizen science: Emerging technologies and shifting paradigms. Frontiers in Ecology and the Environment, 1O(6), 298-304. doi: 10.1890/110294

Nyamba, S. Y., \& Mlozi, M. R. S. (2012). Factors influencing the use of mobile phones in communicating agricultural information: A case of Kilolo District, Iringa, Tanzania. International Journal of Information and Communication Technology, 2(7), 838 - 845. Retrieved from http://esjournals.org/journaloftechnology/archive/vol2no7/vol2no7 3.pdf

Ospina, A. V., \& Heeks, R. (2010). Linking ICTs and climate change adaptation: A conceptual framework for e-Resilience and e-Adaptation. Center for Development Informatics, Institute for Development Policy and Management, SED, Manchester, UK. Retrieved from https://www.escholar.manchester.ac.uk/uk-ac-man-scw:193344

Ospina, A. V., \& Heeks, R. (2011). ICTs and climate change adaptation: Enabling innovative strategies. UK: Strategy Brief, Centre for Development Informatics. University of Manchester. Retrieved from http://www.niccd.org/wpcontent/uploads/2017/11/ICTs and Climate Change Adaptation Strategy Brief.pdf

Paavola, J. (2008). Livelihoods, vulnerability and adaptation to climate change in Morogoro, Tanzania. Environmental Science \& Policy, 11(7), 642-654. doi: 10.1016/j.envsci.2008.06.002

Salami, A., Kamara, A. B., \& Brixiova, Z. (2009). Smallholder agriculture in East Africa: Trends, constraints and opportunities. Discussion paper no. 18. International Livestock Research Institute. Nairobi, Kenya. Retrieved from https://cgspace.cgiar.org/handle/10568/27 
Sanga, C., Kalungwizi, V., \& Msuya, C. (2013). Building agricultural extension services system supported by ICTs in Tanzania: Progress made, challenges remain. International Journal of Education and Development using ICT, 9(1), 80-99. Retrieved from https://files.eric.ed.gov/fulltext/EJ1071386.pdf

Sanga, C., Mlozi, M., Haug, R., \& Tumbo, S. (2016, December 31). Mobile learning bridging the gap in agricultural extension service delivery: Experiences from Sokoine University of Agriculture, Tanzania. International Journal of Education and Development using ICT, 12(3). Retrieved from http://ijedict.dec.uwi.edu/viewarticle.php?id=2201

Sanga, C., Mlozi, M.R.S., Tumbo, S., Mussa, M., Muhiche, L., \& Haug. R.. (2014). On the development of the mobile based agricultural extension system in Tanzania: A technological perspective. International Journal of Computing and ICT Research (IJCIR), 8(1), 49-67. Retrieved from http://ijcir.mak.ac.ug/volume8-number1/article5.pdf

Sanga, C. A., Phillipo, J., Mlozi, M. R., Haug, R., \& Tumbo, S. D. (2016). Crowdsourcing platform 'Ushaurikilimo'enabling questions answering between farmers, extension agents and researchers. International Journal of Instructional Technology and Distance Learning, 10(13), 19-28. Retrieved from http://www.itdl.org/Journal/Oct_16/Oct16.pdf

Sanga, C., Sumari, N., \& Tumbo, S. D. (2013). On the development of climate data visualization tool for interpretation of empirical results from climate model: Does it add value to different stakeholders. Proceedings and Reports of the 6th UbuntuNet Alliance Annual Conference (pp. 223-235). IDRC Digital Library. Retrieved from http://hdl.handle.net/10625/53413

Shackleton, S., Ziervogel, G., Sallu, S., Gill, T., \& Tschakert, P. (2015). Why is socially-just climate change adaptation in Sub-Saharan Africa so challenging? A review of barriers identified from empirical cases. Wiley Interdisciplinary Reviews: Climate Change, 6(3), 321-344. doi: 10.1002/wcc.335

Sife, A. S., Kiondo, E., \& Lyimo-Macha, J. G. (2010). Contribution of mobile phones to rural livelihoods and poverty reduction in Morogoro region, Tanzania. The Electronic Journal of Information Systems in Developing Countries, 42(1), 1-15. doi: 10.1002/j.1681-4835.2010.tbo0299.x

Tall, A., Hansen, J., Jay, A., Campbell, B., Kinyangi, J., Aggarwal, P.K., \& Zougmoré, R. (2014). Scaling up climate services for farmers: Mission Possible. Learning from good practice in Africa and South Asia (CCAFS Report No. 13). Copenhagen: CGIAR Research Program on Climate Change, Agriculture and Food Security (CCAFS). Retrieved from http://bit.ly/1iYMs5 5

Tanko, L., \& Ibeawuchi, J.C. (2006). Econometric study of farmer's patronage of financial institutions in Ikwuano local government area, Abia State, Nigeria. International Journal of Agriculture and Rural Development (IJARD), 7(2), 33-39. doi: 10.4314/ijard.v7i2.2638

Tanzania Communications Regulatory Authority. (2016). TCRA report. Retrieved from https://www.tcra.go.tz/images/documents/telecommunication/CommStatJune16.pdf 
Tanzania Communications Regulatory Authority. (2017). Quarterly communications statistics. Retrieved from https://www.tcra.go.tz/images/documents/telecommunication/TelCom-Statistics-June2017.pdf

Tumbo, S. D. T, Mzirai, O., Mourice, S., Msongaleli, B., Sanga, C., Wambura, F., Kadigi, I., \& Sumari, N. (2015). Impacts of climate change on agriculture: What, when, where and how? Retrieved from http://41.73.194.142:8080/xmlui/handle/123456789/696

United Republic of Tanzania. (2008). Agricultural sector reforms in Tanzania: Perspectives from within. Ministry of Agriculture Food Security and Cooperatives. Dar es Saalam: Government Printers.

United Republic of Tanzania. (2011). Tanzania Agriculture and Food Security Investment Plan (TAFSIP) 2011-12 to 2020-21. Dar es Saalam: Government Printers.

Upadhyay, A. P., \& Bijalwan, A. (2015). Climate change adaptation: services and role of information communication technology (ICT) in India. American Journal of Environmental Protection, 4(1), 70-74. doi: 10.11648/j.ajep.20150401.20

Wyche, S., \& Steinfield, C. (2016). Why don't farmers use cell phones to access market prices? Technology affordances and barriers to market information services adoption in rural Kenya. Information Technology for Development, 22(2), 320-333. doi: 10.1080/02681102.2015.1048184

Zhu, C., Rodríguez-Hidalgo, R. C. R. H., Questier, F., \& Torres-Alfonso, A. M. (2015). Using social network analysis for analysing online threaded discussions. International Journal of Learning, Teaching and Educational Research, 10(3), 128-146. Retrieved from https://cris.vub.be/files/5293661/IJLTER final.pdf 